\title{
First total synthesis of salvianolic acid C, tournefolic acid A, and tournefolal
}

\author{
Si-Da Shen, ${ }^{a}$ Gui-Ping Zhang, ${ }^{\text {b }}$ Min Lei ${ }^{\mathrm{b} *}$ and Li-Hong $\mathrm{Hu}^{\mathrm{a}, \mathrm{b} *}$ \\ ${ }^{a}$ School of Pharmacy, East China University of Science and Technology, 130 Meilong Road, \\ Shanghai 200237, PR of China \\ ${ }^{b}$ Shanghai Research Center for Modernization of Traditional Chinese Medicine, Shanghai \\ Institute of Materia Medica, 501 Haike Road, Shanghai, 201203, PR of China \\ E-mail: mlei@mail.shcnc.ac.cn, simmhulh@mail.shcnc.ac.cn
}

\begin{abstract}
First total synthesis of the natural product salvianolic acid C, tournefolal and tournefolic acid A has been described. The key benzofuran skeletons are prepared via selective iodination and Sonogashira reaction.
\end{abstract}

Keywords: Salvianolic acid C, benzofuran, Sonogashira coupling, iodination

\section{Introduction}

Salvia miltiorrhiza Bunge (Dan-shen) is widely used as a Chinese traditional medicine for the treatment of myocardial infarction, atherosclerosis, and thrombus. ${ }^{1}$ The hydrosoluble salvianolic acids isolated from water-soluble part of Dan-shen are considered as the main pharmacological active ingredients for the activities of anti-oxidative, anticoagulant, antithrombotic, anti-HIV, anti-tumor, and so on. ${ }^{2}$ Salvianolic acid C (1), one of the Salvianolic acids, is constituted of danshensu (2) ${ }^{3}$ and 2-phenyl-benzofuran neolignan tournefolic acid A (3) linked by ester bond. Recently, Liang et al. ${ }^{5}$ have reported that salvianolic acid C (1) displays anti-proliferative activity against $\mathrm{HepG}_{2}$ cells with $\mathrm{IC}_{50}$ value of $20 \mu \mathrm{M}$ through apoptosis, and the mechanism is concerned with inhibition of tubulin polymerization. Furthermore, neolignan tournefolic acid A (3) and tournefolal (4) express valuable anti-lipidperoxidative acitivity. ${ }^{4}$ However, the low contents of salvianolic acid C (1), ${ }^{6}$ tournefolic acid A (3) as well as tournefolal (4) limit for further pharmacological property research. In view of their importance, the development of a route for the synthesis of salvianolic acid C (1), tournefolic acid A (3) as well as tournefolal (4) are of importance.

The 2-phenyl-benzofuran skeleton of $\mathbf{1}$ is a privileged structure in medical chemistry. Several natural compounds containing 2-phenyl-benzofuran, such as XH-14, ${ }^{7}$ obovaten, ${ }^{8}$ and egonol, ${ }^{9}$ 
show significant biological activities. Therefore, due to the importance of 2-phenyl-benzofuran derivatives, many methods for synthesis of these compounds have been developed. ${ }^{10-13}$ However, salvianolic acid C (1), tournefolic acid A (3), and tournefolal (4) have substitutents at C-4, which are distinct from common natural neolignans having substitutents at C-5.

According to the literature, ${ }^{4-6}$ although several groups have isolated salvianolic acid C (1), tournefolic acid A (3), and tournefolal (4) to study their biological activities, the total synthesis of them have not yet been reported. Our group has focused on total synthesis and pharmacological research of natural products for many years. ${ }^{14}$ Herein, we wish to report a route first time on the total synthesis of salvianolic acid C (1), tournefolic acid A (3), and tournefolal (4). And the approach is also suitable for synthesis the C-4 substituted 2-phenyl-benzofuran compounds.

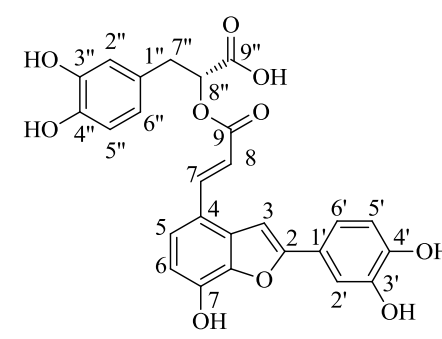

1

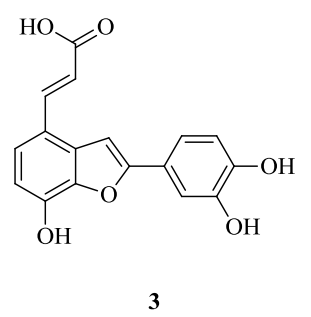

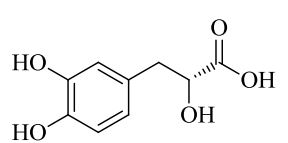

2

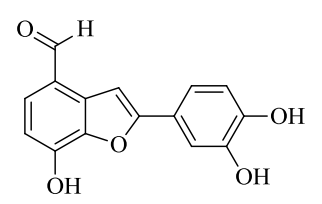

4

Figure 1. Salvianolic acid C (1), danshensu (2), tournefolic acid A (3), and tournefolal (4).

\section{Results and Discussion}

The retrosynthetic analysis of salvianolic acid C (1) is shown in Scheme 1. We hypothesized that 1 could be structured from tournefolic acid A (3) through esterification with danshensu (2). And 3 could be obtained by Knoevenagel condensation from $4{ }^{15}$ The key benzofuran intermediate tournefolal (4) could be synthesized by Sonogashira coupling of 3-hydroxy-2-iodobenzaldehyde (6) and the ethynylbenzene analogues (7). Compound (6) could be prepared from 4dihydroxybenzaldehyde (8), and Compound (7) could be prepared from pyrocatechol (9). To investigate the feasibility of the analysis above, the related experiments were carried out. 

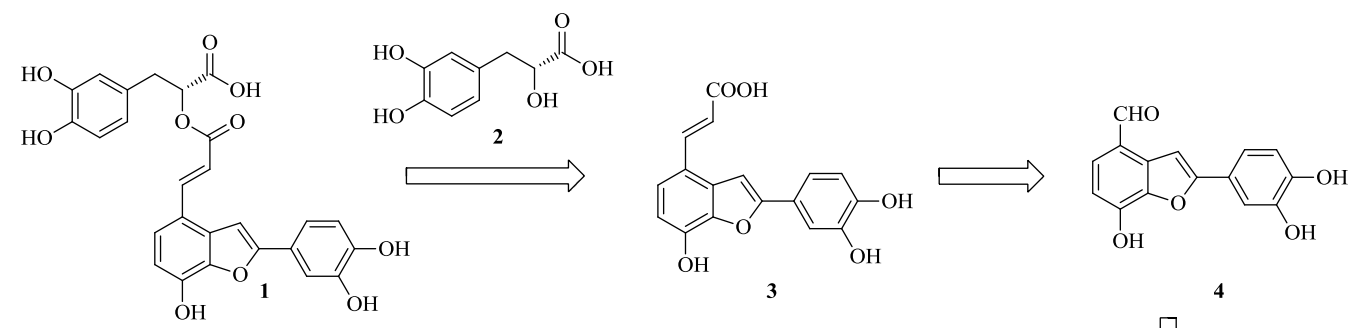

Scheme 1. The retrosynthetic analysis of salvanolic acid C.

As illustrated in Scheme 2, the synthesis of the intermediate 6 was initiated with the selective benzylation at $\mathrm{C}-4(\mathrm{OH})$ of 8 by treatment with $\mathrm{NaI}$, and $\mathrm{NaHCO}_{3}$ at $40{ }^{\circ} \mathrm{C}$ for 2 days, ${ }^{16}$ followed by using iodine chloride to introduce iodine at $\mathrm{C}-2 .{ }^{17} \mathrm{In}$ order to avoid over iodination, the dose of iodine chloride should not exceed 1 eqiv. The other key building block $7^{18}$ was prepared via four steps including benzylation from 9 , iodination catalyzed by iodine and $\mathrm{Ag}_{2} \mathrm{SO}_{4}$, Sonogashira reaction with ethynyltrimethylsilane at r.t., and alkaline hydrolysis reaction. It was noted that the amount of iodine should be subjected to 0.75 eqiv to obtain $\mathbf{1 0}$ in a quantitative yield. If the dose was exceeded, the byproduct of over iodination would be generated.

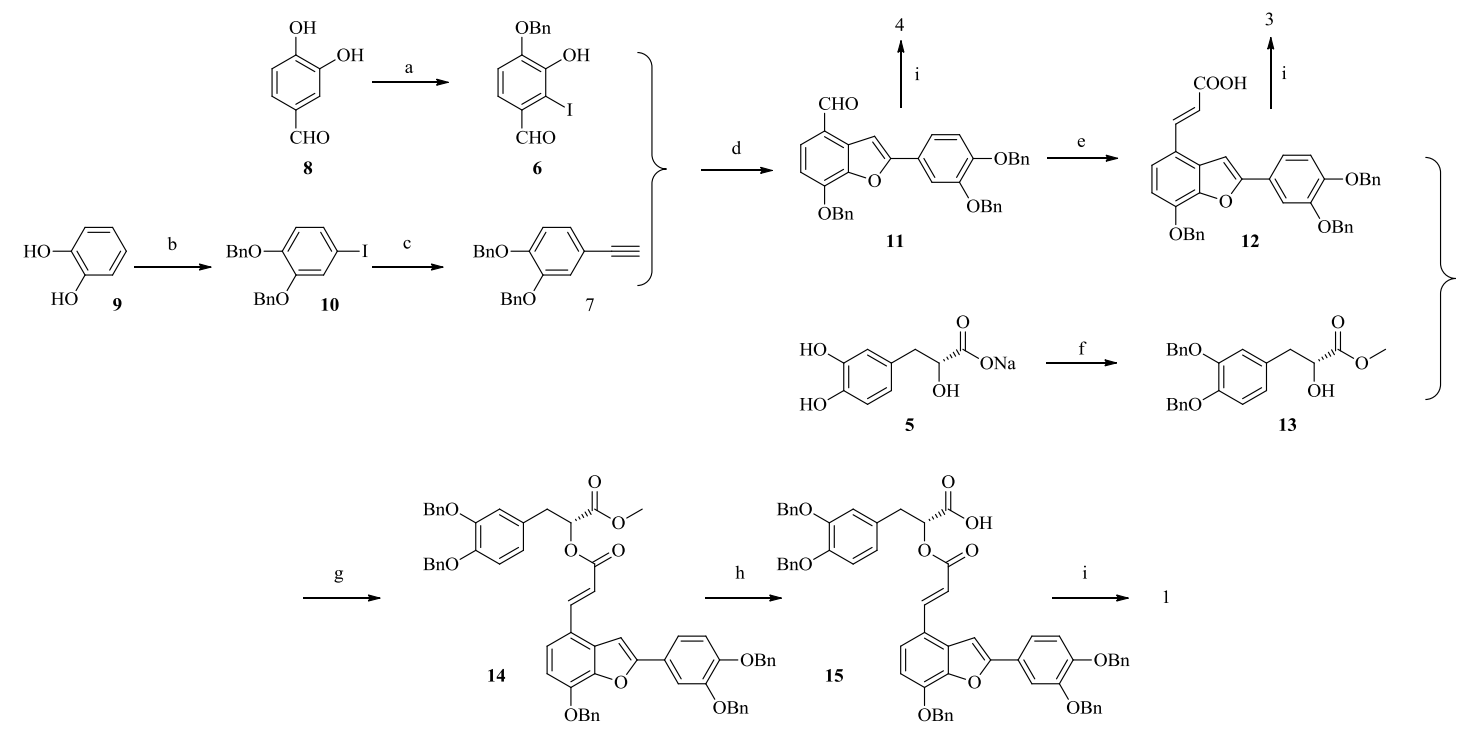

Scheme 2. Reagents and Conditions: a. (i) $\mathrm{NaHCO}_{3}$, NaI, $\mathrm{BnCl}, \mathrm{DMF}, 40{ }^{\circ} \mathrm{C}, 2 \mathrm{~d}, 67 \%$; (ii) $\mathrm{ICl}$, Py, DCM, $0{ }^{\circ} \mathrm{C}-$ r.t., $12 \mathrm{~h}, 86 \%$; b. (i) $\mathrm{K}_{2} \mathrm{CO}_{3}$, BnBr, DMF, r.t., $12 \mathrm{~h}$, 96\%; (ii) $\mathrm{I}_{2}, \mathrm{Ag}_{2} \mathrm{SO}_{4}$, DCM / EtOH, r.t., 1 h, 95\%; c. (i) $\mathrm{Pd}\left(\mathrm{PPh}_{3}\right)_{2} \mathrm{Cl}_{2}$, CuI, TEA, r.t., 12 h, 90\%; (ii) $\mathrm{K}_{2} \mathrm{CO}_{3}$, $\mathrm{MeOH}$, r.t., 24 
h, 94\%; d. $\mathrm{PdCl}_{2}\left(\mathrm{PPh}_{3}\right)_{2}$, CuI, TEA, DMF, $65{ }^{\circ} \mathrm{C}, 12 \mathrm{~h}, 63 \%$; e. piperidine, $\mathrm{Py}, 100{ }^{\circ} \mathrm{C}, 5 \mathrm{~h}, 85 \%$; f. (i) $\mathrm{BnBr}, \mathrm{K}_{2} \mathrm{CO}_{3}, \mathrm{MeOH}$, reflux, $5 \mathrm{~h}$; (ii) $p$ - $\mathrm{TsOH}, \mathrm{MeOH}$, reflux, $4 \mathrm{~h}, 51 \%$, in two steps; g. EDCI, DMAP, DMF, r.t., 2 d, 84\%; h. $\mathrm{Me}_{3} \mathrm{SnOH}$, DCE, reflux, 24 h, 43\%; i. $\mathrm{BBr}_{3}$, DCM, -78 ${ }^{\circ} \mathrm{C}, 1 \mathrm{~h}$.

The Sonogashira coupling ${ }^{13}$ of 6 with 7 was catalyzed by $\left.\mathrm{Pd}_{\left(\mathrm{Ph}_{3} \mathrm{P}\right)}\right)_{2} \mathrm{Cl}_{2}(3 \mathrm{~mol} \%)$ and $\mathrm{CuI}(2$ mol\%) to afford benzofuran aldehyde $\mathbf{1 1}$ as a yellow solid in 63\% yield. Compound $\mathbf{1 2}$ was prepared via Knoevenagel condensation of $\mathbf{1 1}$ with malonic acid in pyridine in $85 \%$ yield with excellent $E / Z$ ratio (95:5). Compound 13, which was prepared from Sodium Danshensu 5 via benzylation and methyl esterification, was esterified with $\mathbf{1 2}$ to produce $\mathbf{1 4}$ in $87 \%$ yield. Considering about the acrylic acid ester bond of $\mathbf{1 4}$, we chose neutral reagent $\mathrm{Me}_{3} \mathrm{SnOH}$ as the catalyst for demethylation to afford $\mathbf{1 5}$ in $43 \%$ yield. ${ }^{14}$ Taking into account the tolerance of double-bond, the debenzylation of $\mathbf{1 5}$ was catalyzed by Lewis acid $\mathrm{BBr}_{3}$ at $-78{ }^{\circ} \mathrm{C}$ to afford $\mathbf{1}$. And we succeeded in obtaining 1 through purification by Sephadex LH-20 in 40\% yield. This method of debenzylation could be applied in the preparation of tournefolic acid A (3) and tournefolal (4) from compound $\mathbf{1 2}$ and $\mathbf{1 1}$, respectively.

\section{Conclusions}

In summary, we have developed a method first time for the total synthesis of salvianolic acid $\mathrm{C}$ (1) (4.5\% yield, in thirteen steps), tournefolic acid A (3) (12.1\% yield, in nine steps), and tournefolal (4) (31.5\% yield, in eight steps). This approach also can be applied to build the C-4 substituted 2-phenyl-benzofuran construction.

\section{Experimental Section}

General. Reagents and all solvents were analytically pure grade and were used without further purification. Column chromatography (CC) was performed on Sephadex LH-20, silica gel (200300 mesh) and RP-18 $(20-45 \mu \mathrm{m}) .{ }^{1} \mathrm{H}(300 \mathrm{MHz})$ and ${ }^{13} \mathrm{C}(75 \mathrm{MHz})$ NMR spectra were recorded on a Varian Mercury 300 spectrometer in the solvent indicated. Chemical shifts are reported in ppm relative to the internal reference. ESIMS were obtained on a Bruker Esquire 3000 Plus spectrometer, and HRESIMS on a Micromass Q-Tof Global mass spectrometer.

4-(Benzyloxy)-3-hydroxy-2-iodobenzaldehyde (6). (1) To a stirred solution of benzaldehyde 8 $(4 \mathrm{~g}, 29.0 \mathrm{mmol})$ in DMF $(50 \mathrm{~mL})$ was added $\mathrm{NaHCO}_{3}(3.65 \mathrm{~g}, 40.0 \mathrm{mmol}), \mathrm{NaI}(1.30 \mathrm{~g}, 8.7$ $\mathrm{mmol})$, and $\mathrm{BnCl}(7 \mathrm{~mL})$. The mixture was stirred at $40{ }^{\circ} \mathrm{C}$ for 2 days. After cooling to r.t., $1 \mathrm{~N}$ $\mathrm{HCl}(50 \mathrm{~mL})$ was added, and the solution was extracted with EtOAc $(3 \times 70 \mathrm{~mL})$. The combined organic layers were washed with brine, dried, filtered, and concentrated under reduced pressure. 
The crude product was purified by recrystallization from DCM/PE to afford a white solid 4(benzyloxy)-3-hydroxy-benzaldehyde (4.4 g, 67\%).

(2) To a stirred solution of 4-(benzyloxy)-3-hydroxybenzaldehyde (0.456 g, $2 \mathrm{mmol})$ and pyridine $(2 \mathrm{~mL})$ in anhydrous DCM $(10 \mathrm{~mL})$ was added $\mathrm{ICl}(1 \mathrm{M}$ in DCM, $2 \mathrm{~mL}, 2 \mathrm{mmol})$. The mixture was stirred for $15 \mathrm{~min}$ at $0{ }^{\circ} \mathrm{C}$, then warmed up to r.t. slowly, and stirred at r.t. overnight under Ar protection. After completion of the reaction, $1 \mathrm{~N} \mathrm{HCl}(10 \mathrm{~mL})$ was added, and the solution was extracted with DCM $(3 \times 20 \mathrm{~mL})$. The combined organic extracts were washed with brine, dried, filtered, and concentrated under reduced pressure. The crude product was purified by chromatography on silica gel $(\mathrm{PE}:$ EtOAc $=9: 1)$ to afford a white solid $6(0.615 \mathrm{~g}, 86 \%)$.

Compound 6. ${ }^{1} \mathrm{H}$ NMR $\left(300 \mathrm{MHz}, \mathrm{CDCl}_{3}\right): \delta 5.22(\mathrm{~s}, 2 \mathrm{H}), 6.36(\mathrm{~s}, 1 \mathrm{H}), 6.97(\mathrm{~d}, J=8.7 \mathrm{~Hz}$, $1 \mathrm{H}), 7.41(\mathrm{~m}, 5 \mathrm{H}), 7.52(\mathrm{~d}, J=8.7 \mathrm{~Hz}, 1 \mathrm{H}), 10.04(\mathrm{~s}, 1 \mathrm{H}) .{ }^{13} \mathrm{C} \mathrm{NMR}\left(75 \mathrm{MHz}, \mathrm{CDCl}_{3}\right): \delta 71.9$, 88.6, 111.5, 123.9, 128.1(2C), 129.1, 129.2(2C) 135.1(2C), 146.2, 150.1, 195.0. MS (ESI): $\mathrm{m} / z$ $355.0[\mathrm{M}+\mathrm{H}]^{+}$. HRMS (ESI): $m / z[\mathrm{M}+\mathrm{H}]^{+}$Calcd for $\mathrm{C}_{14} \mathrm{H}_{12} \mathrm{IO}_{3}: 354.9831$; found: 354.9835 .

3,4-Dibenzyloxyiodobenzene (10). (1) To a stirred solution of pyrocatechol 10 (5.5 g, 0.05 mol,) and $\mathrm{K}_{2} \mathrm{CO}_{3}(25 \mathrm{~g}, 0.2 \mathrm{~mol}, 4.0$ equiv) in $\mathrm{DMF}(50 \mathrm{~mL})$ was added $\mathrm{BnBr}(24 \mathrm{~mL}, 0.2 \mathrm{~mol})$. The reation mixture was degassed, charged with Ar, and stirred at r.t. overnight. After completion of the reaction, the mixture was filtered, and the solvent of the filtrate was removed under reduced pressure at $80{ }^{\circ} \mathrm{C}$. The crude product was purified by recrystallization from $\mathrm{MeOH}$ to afford a white solid 1,2-dibenzyloxybenzene $(14.1 \mathrm{~g}, 96 \%)$.

(2) To a stirred solution of 1,2-dibenzyloxybenzene $(5.8 \mathrm{~g}, 20 \mathrm{mmol})$ and $\mathrm{Ag}_{2} \mathrm{SO}_{4}(9.3 \mathrm{~g}, 30$ $\mathrm{mmol})$ in EtOH / DCM (100/50 mL) was added $\mathrm{I}_{2}(4.14 \mathrm{~g}, 15 \mathrm{mmol})$. The reaction was stirred at r.t. for $1 \mathrm{~h}$. After completion of the reaction, the mixture was filtered, and the solvent of the filtrate was removed under reduced pressure. The crude product was purified by recrystallization from $\mathrm{MeOH}$ to afford a white solid $10(7.94 \mathrm{~g}, 95 \%)$.

Compound 10. ${ }^{1} \mathrm{H}$ NMR $\left(300 \mathrm{MHz}, \mathrm{CDCl}_{3}\right): \delta 5.11(\mathrm{~s}, 2 \mathrm{H}), 5.12(\mathrm{~s}, 2 \mathrm{H}), 6.70(\mathrm{~d}, J=8.4 \mathrm{~Hz}$, $1 \mathrm{H}), 7.17(\mathrm{dd}, J=8.7 \mathrm{~Hz}, J=2.4 \mathrm{~Hz}, 1 \mathrm{H}), 7.23(\mathrm{~d}, J=2.4 \mathrm{~Hz}, 1 \mathrm{H}), 7.29-7.45(\mathrm{~m}, 10 \mathrm{H}) .{ }^{13} \mathrm{C}$ NMR (75 MHz, $\left.\mathrm{CDCl}_{3}\right): \delta 71.5,71.7,83.5,117.3,124.2,127.2(2 \mathrm{C}), 127.5,127.6,127.7,127.9$, 128.2, 128.3, 128.8, 128.9, 130.8, 136.9, 137.1, 149.3, 150.2. MS (ESI): $m / z 439.3$ [M+Na] $^{+}$. HRMS (ESI): $\mathrm{m} / z$ [M+Na] ${ }^{+}$Calcd for $\mathrm{C}_{20} \mathrm{H}_{17} \mathrm{IO}_{2} \mathrm{Na}$ : 439.0171 ; found: 439.0173 .

3,4-Dibenzyloxyethylbenzene (7). (1) To a stirred solution of $\mathbf{1 0}(0.98 \mathrm{~g}, 2.36 \mathrm{mmol}), 3 \mathrm{~mol} \%$ $\mathrm{Pd}\left(\mathrm{PPh}_{3}\right)_{2} \mathrm{Cl}_{2}(50 \mathrm{mg}, 0.07 \mathrm{mmol})$, and $3 \mathrm{~mol} \% \mathrm{CuI}(9 \mathrm{mg}, 0.047 \mathrm{mmol})$ in TEA (20 mL) were added (trimethylsilyl)acetylene $(0.37 \mathrm{~mL}, 2.60 \mathrm{mmol})$. The reation mixture was degassed, charged with Ar, and stirred at r.t. overnight. After completion of the reaction, $1 \mathrm{~N} \mathrm{HCl}(20 \mathrm{~mL})$ was added, and the aqueous layer was extracted with EtOAc $(3 \times 40 \mathrm{~mL})$, and the combined organic layers were dried, filtered, and concentrated under reduced pressure. The crude product was purified by chromatography on silica gel (PE : EtOAc $=8: 1)$ to afford a colorless oil 3,4dibenzyloxytrimethyl- (phenylethynyl)silane (820 mg, 90\%). 
(2) To a stirred solution of 3,4-Dibenzyloxytrimethyl(phenylethynyl)silane (0.82 g, $2.12 \mathrm{mmol})$ in $\mathrm{MeOH}(50 \mathrm{~mL})$ was added $\mathrm{K}_{2} \mathrm{CO}_{3}(1.465 \mathrm{~g}, 10.5 \mathrm{mmol})$. The reaction was stirred at r.t. for 24 h. After completion of the reaction, the mixture was filtered, and the solvent of filtrate was removed under reduced pressure. The crude product was purified by recrystallization from $\mathrm{MeOH}$ to afford a white solid 7 (0.625 g, 94\%).

Compound 7: ${ }^{1} \mathrm{H}$ NMR $\left(300 \mathrm{MHz}, \mathrm{CDCl}_{3}\right): \delta 2.98(\mathrm{~s}, 1 \mathrm{H}), 5.14(\mathrm{~s}, 2 \mathrm{H}), 5.17(\mathrm{~s}, 2 \mathrm{H}), 6.85(\mathrm{~d}, J=$ $8.1 \mathrm{~Hz}, 1 \mathrm{H}), 7.085(\mathrm{~d}, J=8.1 \mathrm{~Hz}, 1 \mathrm{H}), 7.087(\mathrm{~s}, 1 \mathrm{H}), 7.33-7.44(\mathrm{~m}, 10 \mathrm{H}) .{ }^{13} \mathrm{C}$ NMR $(75 \mathrm{MHz}$, $\left.\mathrm{CDCl}_{3}\right): \delta 71.3,71.6,76.3,84.0,114.7,115.2,115.6,118.6,122.0,126.4,127.5,127.6128 .1$, 128.2, 128.7(2C), 128.8(2C), 137.1, 137.2, 148.8, 150.1. MS (ESI): $\mathrm{m} / z 315.3[\mathrm{M}+\mathrm{H}]^{+}$. HRMS (ESI): $m / z[\mathrm{M}+\mathrm{H}]^{+}$Calcd for $\mathrm{C}_{22} \mathrm{H}_{19} \mathrm{O}_{2}: 315.1385$; found: 315.1390 .

7-(Benzyloxy)-2-(3,4-bis(benzyloxy)phenyl)benzo-[b]furan-4-carbaldehyde (11). To a stirred solution of the above iodophenol 6 (177 mg, $0.5 \mathrm{mmol}), 3 \mathrm{~mol} \% \mathrm{Pd}\left(\mathrm{PPh}_{3}\right)_{2} \mathrm{Cl}_{2}(15 \mathrm{mg})$, and ethynylbenzene 7 ( $157 \mathrm{mg}, 0.5 \mathrm{mmol})$ in DMF $(5 \mathrm{~mL})$ was added TEA $(5 \mathrm{~mL})$. The mixture was stirred for $15 \mathrm{~min}$ before $2 \mathrm{~mol} \% \mathrm{CuI}(15 \mathrm{mg})$ was added. The reation mixture was degassed, charged with Ar, and stirred at $65^{\circ} \mathrm{C}$ overnight. After cooling to r.t., $1 \mathrm{~N} \mathrm{HCl}(7 \mathrm{~mL})$ was added, and the aqueous layer was extracted with EtOAc $(3 \times 15 \mathrm{~mL})$, and the combined organic layers were dried, filtered, and concentrated under reduced pressure. The crude product was purified by chromatography on silica gel (PE : EtOAc $=4: 1)$ to afford a yellow solid $11(170 \mathrm{mg}, 63 \%)$.

Compound 11. ${ }^{1} \mathrm{H}$ NMR $\left(300 \mathrm{MHz}, \mathrm{CDCl}_{3}\right): \delta 5.21(\mathrm{~s}, 2 \mathrm{H}), 5.24(\mathrm{~s}, 2 \mathrm{H}), 5.43(\mathrm{~s}, 2 \mathrm{H}), 6.90(\mathrm{~d}, J$ $=8.7 \mathrm{~Hz}, 1 \mathrm{H}), 6.95(\mathrm{~d}, J=8.7 \mathrm{~Hz}, 1 \mathrm{H}), 7.33-7.54(\mathrm{~m}, 17 \mathrm{H}), 7.59(\mathrm{~d}, J=8.1 \mathrm{~Hz}, 1 \mathrm{H}), 7.65(\mathrm{~s}$, $1 \mathrm{H}), 10.03(\mathrm{~s}, 1 \mathrm{H}) .{ }^{13} \mathrm{C} \mathrm{NMR}\left(75 \mathrm{MHz}, \mathrm{CDCl}_{3}\right): \delta 71.4,71.5,71.7,101.1,108.0,112.4,115.1$, $119.6,123.1,123.5,127.5(3 \mathrm{C}), 127.7(3 \mathrm{C}), 127.8,128.2,128.6(2 \mathrm{C}), 128.8(2 \mathrm{C}), 128.9(3 \mathrm{C})$, 131.9(2C), 137.2(3C), 148.9, 149.4(2C), 150.4, 159.3, 191.1. MS (ESI): $\mathrm{m} / z 541.3[\mathrm{M}+\mathrm{H}]^{+}$. HRMS (ESI): $m / z[\mathrm{M}+\mathrm{H}]^{+}$Calcd for $\mathrm{C}_{36} \mathrm{H}_{29} \mathrm{O}_{5}$ : 541.2015; found: 541.2020.

(E)-3-(7-(Benzyloxy)-2-(3,4-bis(benzyloxy)phenyl)be-nzo[b]furan-4-yl)acrylic acid (12). To a stirred solution of $11(500 \mathrm{mg}, 0.925 \mathrm{mmol}$,) in pyridine $(25 \mathrm{~mL})$ was added malonic acid (288 $\mathrm{mg}, 2.78 \mathrm{mmol})$ and piperidine $(0.25 \mathrm{~mL})$. The reaction mixture was heated to $100{ }^{\circ} \mathrm{C}$ for $5 \mathrm{~h}$. After cooling to r.t., $1 \mathrm{~N} \mathrm{HCl}(15 \mathrm{~mL})$ was added, the aqueous layer was extracted with EtOAc (3 $\times 20 \mathrm{~mL}$ ), and the combined organic layers were dried, filtered, and concentrated under reduced pressure. The crude product was purified by recrystallization from $\mathrm{Et}_{2} \mathrm{O}$ to afford a yellow solid $12(458 \mathrm{mg}, 85 \%)$.

Compound 12. ${ }^{1} \mathrm{H}$ NMR $\left(300 \mathrm{MHz}, \mathrm{DMSO}-d_{6}\right): \delta 5.18$ (s, 2H), $5.24(\mathrm{~s}, 2 \mathrm{H}), 5.39$ (s, 2H), 6.50 $(\mathrm{d}, J=16.2 \mathrm{~Hz}, 1 \mathrm{H}), 7.03(\mathrm{~d}, J=8.4 \mathrm{~Hz}, 1 \mathrm{H}), 7.18(\mathrm{~d}, J=8.4 \mathrm{~Hz}, 1 \mathrm{H}), 7.23-7.56(\mathrm{~m}, 17 \mathrm{H}), 7.71$ $(\mathrm{d}, J=1.5 \mathrm{~Hz}, 1 \mathrm{H}), 7.79(\mathrm{~s}, 1 \mathrm{H}), 7.81(\mathrm{~d}, J=15.9 \mathrm{~Hz}, 1 \mathrm{H}), 12.31(\mathrm{~s}, 1 \mathrm{H}) .{ }^{13} \mathrm{C}$ NMR $(75 \mathrm{MHz}$, DMSO- $\left.d_{6}\right): \delta 70.7,71.0,71.0,100.8,109.6,111.9,115.1,118.2,118.9,120.4,123.2,125.7$, 128.3(4C), 128.4(3C), 128.5(2C), 128.8, 129.1, 129.3(4C), 131.0, 137.3, 137.7, 137.8, 142.1, 143.9, 145.8, 149.3, 150.0, 157.3, 168.7. MS (ESI): $m / z 581.4$ [M-H] $]^{-}$HRMS (ESI): $m / z$ [M-H] ${ }^{-}$ Calcd for $\mathrm{C}_{38} \mathrm{H}_{29} \mathrm{O}_{6}$ : 581.1964; found: 581.1969 . 
(R)-Methyl 3-(3,4-bis(benzyloxy)phenyl)-2-hydroxy-propanoate (13). (1) To a stirred solution of Sodium Danshensu 5 (220 mg, $1 \mathrm{mmol})$ in $\mathrm{MeOH}(50 \mathrm{~mL})$ was added $\mathrm{K}_{2} \mathrm{CO}_{3}(550 \mathrm{mg}, 4$ $\mathrm{mmol})$, and $\mathrm{BnBr}(0.25 \mathrm{~mL}, 3 \mathrm{mmol})$. The reaction mixture was degassed, charged with Ar, and heated to reflux $5 \mathrm{~h}$. After cooling to r.t., the solvent of the mixture was removed under reduced pressure. The crude product was used for the next step directly.

(2) To a stirred solution of the above crude material in $\mathrm{MeOH}(20 \mathrm{~mL})$ was added $p$ - $\mathrm{TsOH}(3$ $\mathrm{mg}, 0.01 \mathrm{mmol})$. The reaction mixture was heated to reflux for $4 \mathrm{~h}$. After cooling to r.t., the solvent of the mixture was removed under reduced pressure. The crude product was purified by chromatography on silica gel (PE : EtOAc $=4: 1)$ to afford a white solid $13(190 \mathrm{mg}, 51 \%$, in two steps).

Compound 13: $[\alpha]_{\mathrm{D}}{ }^{20}+14\left(c 0.05, \mathrm{CHCl}_{3}\right) .{ }^{1} \mathrm{H}$ NMR $\left(300 \mathrm{MHz}, \mathrm{CDCl}_{3}\right): \delta 2.61(\mathrm{~d}, J=6.6 \mathrm{~Hz}$, $1 \mathrm{H}), 2.85$ (dd, $J=14.1,6.6 \mathrm{~Hz}, 1 \mathrm{H}), 3.02(\mathrm{dd}, J=14.1,4.4 \mathrm{~Hz}, 1 \mathrm{H}), 3.71(\mathrm{~s}, 3 \mathrm{H}), 4.38(\mathrm{td}, J=$ 6.6, 4.4, 1H), $5.13(\mathrm{~s}, 2 \mathrm{H}), 5.14(\mathrm{~s}, 2 \mathrm{H}), 6.69(\mathrm{dd}, J=8.4,2.1 \mathrm{~Hz}, 1 \mathrm{H}), 6.82(\mathrm{~d}, J=1.8 \mathrm{~Hz}, 1 \mathrm{H})$, $6.86(\mathrm{~d}, J=8.1 \mathrm{~Hz}, 1 \mathrm{H}), 7.27-7.45(\mathrm{~m}, 10 \mathrm{H}) .{ }^{13} \mathrm{C} \mathrm{NMR}\left(75 \mathrm{MHz}, \mathrm{CDCl}_{3}\right): \delta 40.3,52.6,71.5$, 71.6(2C), 115.4, 116.9, 122.7, 127.5(2C), 127.6(2C), 128.0(2C), 128.1(2C), 128.7(2C), 129.8, 137.6, 137.6, 148.3, 149.1, 174.7. MS (ESI): $m / z 393.3[\mathrm{M}+\mathrm{H}]^{+}$. HRMS (ESI): $m / z[\mathrm{M}+\mathrm{H}]^{+}$ Calcd for $\mathrm{C}_{24} \mathrm{H}_{25} \mathrm{O}_{5}$ : 393.1702; found: 393.1698 .

$(R, E)-1-m e t h o x y c a r b o n y l-2-[3,4-b i s(b e n z y l o x y) p h e n y l] e t h y l$

3-[7-(benzyloxy)-2-[(3,4bis(benzyloxy)phenyl]benzofuran-4-yl]acrylate (14). To a stirred solution of 12 (100 mg, 0.17 $\mathrm{mmol})$ and 13 (80 mg, $0.21 \mathrm{mmol})$ in DMF was added EDCI (177 mg, $0.92 \mathrm{mmol})$, and DMAP (113 $\mathrm{mg}, 0.92 \mathrm{mmol}$ ). The reation mixture was degassed, charged with Ar, and stirred at r.t. for 2 days. After completion of the reaction, $1 \mathrm{~N} \mathrm{HCl}(5 \mathrm{~mL})$ was added, the aqueous layer was extracted with EtOAc $(3 \times 15 \mathrm{~mL})$. The combined organic layers were dried, filtered, and concentrated under reduced pressure. The crude product was purified by chromatography on silica gel (PE : EtOAc $=3: 1)$ to a yellow solid afford $14(140 \mathrm{mg}, 84 \%)$.

Compound 14. $[\alpha]_{\mathrm{D}}{ }^{20}+33\left(c 0.09, \mathrm{CHCl}_{3}\right) .{ }^{1} \mathrm{H}$ NMR $\left(300 \mathrm{MHz}, \mathrm{CDCl}_{3}\right): \delta 3.16(\mathrm{~m}, 2 \mathrm{H}), 3.73$ $(\mathrm{s}, 3 \mathrm{H}), 5.12(\mathrm{~s}, 4 \mathrm{H}), 5.21(\mathrm{~s}, 2 \mathrm{H}), 5.26(\mathrm{~s}, 2 \mathrm{H}), 5.35(\mathrm{~m}, 1 \mathrm{H}), 5.37(\mathrm{~s}, 2 \mathrm{H}), 6.46(\mathrm{~d}, J=15.0 \mathrm{~Hz}$, $1 \mathrm{H}), 6.81(\mathrm{~d}, J=6.0 \mathrm{~Hz}, 2 \mathrm{H}), 6.89(\mathrm{~d}, J=9.0 \mathrm{~Hz}, 2 \mathrm{H}), 6.98(\mathrm{~d}, J=9.0 \mathrm{~Hz}, 1 \mathrm{H}), 7.11(\mathrm{~s}, 1 \mathrm{H})$, 7.26-7.50 (m, 27H), $7.64(\mathrm{~m}, 1 \mathrm{H}), 7.93(\mathrm{~d}, J=15.0 \mathrm{~Hz}, 1 \mathrm{H}) .{ }^{13} \mathrm{C} \mathrm{NMR}\left(75 \mathrm{MHz}, \mathrm{CDCl}_{3}\right): \delta 37.3$, 52.6, 71.3, 71.4, 71.5, 71.6, 71.7, 73.2, 99.5, 109.1, 112.3, 115.0, 115.2, 115.3, 116.6, 119.4, 120.2, 122.6, 123.5, 125.3, 127.5(4C), 127.7(2C), 127.9(2C), 128.1(2C), 128.5(3C), 128.6(4C), 128.8(5C), 128.9(3C), 129.5, 131.2, 136.7, 137.1, 137.3(2C), 137.5, 144.1(2C), 146.2, 148.4, 149.1, 149.3, 150.2, 157.7, 166.9, 170.7. MS (ESI): $\mathrm{m} / \mathrm{z} 979.3[\mathrm{M}+\mathrm{Na}]^{+}$. HRMS (ESI): $\mathrm{m} / z$ $[\mathrm{M}+\mathrm{Na}]^{+}$Calcd for $\mathrm{C}_{62} \mathrm{H}_{52} \mathrm{O}_{10} \mathrm{Na}$ : 979.3458; found: 979.3461 .

\section{(R,E)-2-(3-(7-(Benzyloxy)-2-(3,4-bis(benzyloxy)phen-yl)benzofuran-4-yl)acryloyloxy)-3-}

(3,4-bis(benzyl-oxy)phenyl)propanoic acid (15). To a stirred solution of 14 (90 mg, 0.094 $\mathrm{mmol})$ in DCE $(5 \mathrm{~mL})$ was added $\mathrm{Me}_{3} \mathrm{SnOH}(54 \mathrm{mg}, 0.28 \mathrm{mmol})$. The reaction mixture was heated to reflux overnight. After cooling to r.t., $1 \mathrm{~N} \mathrm{HCl}(5 \mathrm{~mL})$ was added, the aqueous layer 
was extracted with EtOAc $(3 \times 10 \mathrm{~mL})$, and the combined organic layers were dried, filtered, and concentrated under reduced pressure. The crude product was purified by chromatography on silica gel (DCM : $\mathrm{MeOH}=99: 1)$ to afford a yellow solid $15(38 \mathrm{mg}, 43 \%)$.

Compound 15. $[\alpha]_{\mathrm{D}}{ }^{20}+28\left(c 0.07, \mathrm{CHCl}_{3}\right) .{ }^{1} \mathrm{H}$ NMR $\left(300 \mathrm{MHz}, \mathrm{CDCl}_{3}\right): \delta 3.15(\mathrm{~m}, 2 \mathrm{H}), 5.11$ $(\mathrm{s}, 2 \mathrm{H}), 5.19(\mathrm{~s}, 2 \mathrm{H}), 5.23(\mathrm{~s}, 2 \mathrm{H}), 5.30(\mathrm{~s}, 2 \mathrm{H}), 5.39(\mathrm{~s}, 2 \mathrm{H}), 5.40(\mathrm{~m}, 1 \mathrm{H}), 6.43(\mathrm{~d}, J=15.9 \mathrm{~Hz}$, $1 \mathrm{H}), 6.75-6.98(\mathrm{~m}, 7 \mathrm{H}), 7.09(\mathrm{~s}, 1 \mathrm{H}), 7.24-7.53(\mathrm{~m}, 26 \mathrm{H}), 7.93(\mathrm{~d}, J=15.9 \mathrm{~Hz}, 1 \mathrm{H}) .{ }^{13} \mathrm{C}$ NMR $\left(75 \mathrm{MHz}, \mathrm{CDCl}_{3}\right): \delta 36.8,71.0,71.1,71.2,71.3,71.4,72.6,99.2,108.7,111.9,114.7(2 \mathrm{C}), 114.9$, $116.4,119.1,119.8,122.4,123.2,125.1,127.2(2 \mathrm{C}), 127.2(2 \mathrm{C}), 127.3(2 \mathrm{C}), 127.4(2 \mathrm{C})$, 127.5(2C), 127.7(2C), 127.9(2C), 128.1, 128.2, 128.3(2C), 128.4(2C), 128.5(3C), 128.6(2C), 129.1, 131.0, 136.4, 136.8, 137.0, 137.1, 137.2, 143.9, 144.1(2C), 145.9, 148.1, 148.7, 149.9, 157.7, 166.7, 174.8. MS (ESI): $m / z 943.3[\mathrm{M}+\mathrm{H}]^{+}$. HRMS (ESI): $m / z[\mathrm{M}+\mathrm{H}]^{+}$Calcd for $\mathrm{C}_{61} \mathrm{H}_{51} \mathrm{O}_{10}$ : 943.3482; found: 943.3485 .

Salvianolic acid C (1). To a stirred solution of 15 (100 mg, $0.106 \mathrm{mmol})$ in dry DCM (5 mL), $\mathrm{BBr}_{3}\left(2 \mathrm{M}\right.$ in DCM, $0.53 \mathrm{~mL}, 1.06 \mathrm{mmol}$ ) was added at $-78^{\circ} \mathrm{C}$. Then the mixture was stirred at the same temperature for $2 \mathrm{~h}$. After completion of the reaction, $0.5 \mathrm{~mol} / \mathrm{L} \mathrm{Na}_{2} \mathrm{HPO}_{4}(5 \mathrm{~mL})$ was added to quench the reaction. The aqueous layer was extracted with EtOAc $(3 \times 15 \mathrm{~mL})$. The combined organic layers were dried, filtered, and concentrated under reduced pressure. The crude product was purified by Sephadex LH-20 to afford a yellow solid 1 (20 mg, 40\%).

Salvianolic Acid C (1). $[\alpha]_{\mathrm{D}}{ }^{20}+8(c 0.06, \mathrm{MeOH}) .{ }^{1} \mathrm{H}$ NMR $\left(300 \mathrm{MHz}, \mathrm{CD}_{3} \mathrm{OD}\right): \delta 2.97$ (dd, $J$ $=14.1,9.3 \mathrm{~Hz}, 1 \mathrm{H}), 3.15(\mathrm{dd}, J=14.1,3.3 \mathrm{~Hz}, 1 \mathrm{H}), 5.14(\mathrm{dd}, J=9.3,3.3 \mathrm{~Hz}, 1 \mathrm{H}), 6.42(\mathrm{~d}, J=$ $15.9,1 \mathrm{H}), 6.42-6.71(\mathrm{~m}, 3 \mathrm{H}), 6.80(\mathrm{~s}, 1 \mathrm{H}), 6.86(\mathrm{~d}, J=8.4 \mathrm{~Hz}, 1 \mathrm{H}), 7.15(\mathrm{~s}, 1 \mathrm{H}), 7.27(\mathrm{~d}, J=8.4$ $\mathrm{Hz}, 1 \mathrm{H}), 7.35(\mathrm{dd}, J=8.1,2.1 \mathrm{~Hz}, 1 \mathrm{H}), 7.39(\mathrm{~d}, J=1.8 \mathrm{~Hz}, 1 \mathrm{H}), 7.89(\mathrm{~d}, J=15.9 \mathrm{~Hz}, 1 \mathrm{H}) .{ }^{13} \mathrm{C}$ NMR (75 MHz, $\left.\mathrm{CD}_{3} \mathrm{OD}\right): \delta 37.7,76.6,98.3,111.4,112.1,113.6,115.1,115.5,116.4,117.3$, $117.4,120.6,122.4,125.5,128.7,130.1,131.1,143.5,143.6,144.1,144.8,145.6,146.7,157.6$, 168.5, 176.7. MS (ESI): $m / z$ 515.1 $[\mathrm{M}+\mathrm{Na}]^{+}$. HRMS (ESI): $m / z \quad[\mathrm{M}+\mathrm{Na}]^{+}$Calcd for $\mathrm{C}_{26} \mathrm{H}_{20} \mathrm{O}_{10} \mathrm{Na}$ : 515.0954; found: 515.0950.

Tournefolic acid A (3). To a stirred solution of 12 (116 mg, $0.20 \mathrm{mmol})$ in dry DCM (5 mL), $\mathrm{BBr}_{3}(2 \mathrm{M}$ in DCM, $1 \mathrm{~mL}, 2.0 \mathrm{mmol})$ was added at $-78{ }^{\circ} \mathrm{C}$. Then the mixture was stirred at the same temperature for $2 \mathrm{~h}$. After completion of the reaction, $0.5 \mathrm{~mol} / \mathrm{L} \mathrm{Na} \mathrm{HPO}_{4}(5 \mathrm{~mL})$ was added to quench the reaction. The aqueous layer was extracted with EtOAc $(3 \times 15 \mathrm{~mL})$. The combined organic layers were dried, filtered, and concentrated under reduced pressure. The crude product was purified by Sephadex LH-20 to afford a yellow solid $\mathbf{3}$ (27 mg, 45\%).

Tournefolic acid A (3). ${ }^{1} \mathrm{H}$ NMR of $3\left(300 \mathrm{MHz}, \mathrm{Me}_{2} \mathrm{CO}-d_{6}\right): \delta 6.47(\mathrm{~d}, J=16.2 \mathrm{~Hz}, 1 \mathrm{H}), 6.83$ $(\mathrm{d}, J=8.4 \mathrm{~Hz}, 1 \mathrm{H}), 6.93$ (d, $J=8.4 \mathrm{~Hz}, 1 \mathrm{H}), 7.39$ (d, $J=8.1 \mathrm{~Hz} .1 \mathrm{H}), 7.41$ (dd, $J=8.4,2.1 \mathrm{~Hz}$, 1H), 7.45 (s, 1H), $7.51(\mathrm{~d}, J=2.1 \mathrm{~Hz}, 1 \mathrm{H}), 7.90(\mathrm{~d}, J=16.2 \mathrm{~Hz}, 1 \mathrm{H}) .{ }^{13} \mathrm{C} \mathrm{NMR}$ of $\mathbf{3}(75 \mathrm{MHz}$, $\left.\mathrm{Me}_{2} \mathrm{CO}-d_{6}\right): \delta 98.8,110.9,112.5,115.5,115.9,117.7,118.7,122.2,125.4,131.4,143.1,143.2$, 144.7, 145.7, 146.9, 158.0, 168.5. MS (ESI): $m / z$ 313.1 $[\mathrm{M}+\mathrm{H}]^{+}$. HRMS (ESI): $m / z .[\mathrm{M}+\mathrm{H}]^{+}$ Calcd for $\mathrm{C}_{17} \mathrm{H}_{13} \mathrm{O}_{6}$ : 313.0712; found: 313.0708 . 
Tournefolal (4). To a stirred solution of 11 (180 mg, $0.33 \mathrm{mmol})$ in dry DCM (5 mL), $\mathrm{BBr}_{3}(2$ $\mathrm{M}$ in DCM, $1.65 \mathrm{~mL}, 3.3 \mathrm{mmol}$ ) was added at $-78{ }^{\circ} \mathrm{C}$. Then the mixture was stirred at the same temperature for $2 \mathrm{~h}$. After completion of the reaction, $0.5 \mathrm{~mol} / \mathrm{L} \mathrm{Na}_{2} \mathrm{HPO}_{4}(5 \mathrm{~mL})$ was added to quench the reaction. The aqueous layer was extracted with EtOAc $(3 \times 15 \mathrm{~mL})$. The combined organic layers were dried, filtered, and concentrated under reduced pressure. The crude product was purified by Sephadex LH-20 to afford a yellow solid 4 (78 mg, 87\%).

Tournefolal (4). ${ }^{1} \mathrm{H}$ NMR $\left(300 \mathrm{MHz}, \mathrm{Me}_{2} \mathrm{CO}-d_{6}\right): \delta 6.93(\mathrm{~d}, J=9.0 \mathrm{~Hz}, 1 \mathrm{H}), 6.96(\mathrm{~d}, J=8.1 \mathrm{~Hz}$, $1 \mathrm{H}), 7.39(\mathrm{dd}, J=8.1,2.1 \mathrm{~Hz}, 1 \mathrm{H}), 7.48(\mathrm{~d}, J=2.1 \mathrm{~Hz}, 1 \mathrm{H}), 7.6(\mathrm{~s}, 1 \mathrm{H}), 7.66$ (d, $J=7.8 \mathrm{~Hz}$, $1 \mathrm{H}) .{ }^{13} \mathrm{C}$ NMR $\left(75 \mathrm{MHz}, \mathrm{Me}_{2} \mathrm{CO}-d_{6}\right): \delta 99.8,110.4,112.5,115.9,117.9,121.8,121.9,130.9$, 132.1, 143.2, 145.8, 147.2, 148.1, 159.6, 190.6. MS (ESI): $m / z$ 271.1 [M+H] ${ }^{+}$. HRMS (ESI): $m / z$ $[\mathrm{M}+\mathrm{H}]^{+}$Calcd for $\mathrm{C}_{15} \mathrm{H}_{11} \mathrm{O}_{5}: 271.0606$; found: 271.0609 .

\section{Acknowledgements}

This work was supported by the National Natural Science Foundation of China (grants 90713046, 30925040) and CAS Foundation (grant KSCX2-YW-R-179).

\section{References}

1. (a) Cheng, T. O. Int. J. Cardol. 2007, 121, 9. (b) Wang, X. B.; Morris-Natschke, S. L.; Lee, K. H. Med. Res. Rev. 2007, 27, 133. (c) Zhou, L.; Zuo, Z.; Chow, M. S. J. Clin. Pharmacol. $\mathbf{2 0 0 5}, 45,1345$.

2. (a) Lu, Y. R.; Foo, L. Y. Tetrahedron Lett. 2001, 42, 8223. (b) Yang, X. N.; Wang, Y. J.; Liu, Y. S.; Tang, X. J. Ethnopharmacol. 2008, 117, 408. (c) Ouyang, X. S.; Takahashi, K.; Komatsu. K.; Nakamura. N.; Hattori. Baba. A; Azuma. J. Jpn. J. Pharmacol. 2001, 87, 289. (d) Wu, Y. T.; Chen, Y. F.; Hsieh, Y. J. ;Jaw, I. ;Shiao, M. S.; Tsai, T. H. Int. J. Pharm. 2006, 326, 25. (e) Zhao, J. F.; Liu, C. H.; Hu, Y. Y.; Xu, L. M.; Liu, P.; Liu, C. Hepatob. Pancr. Dis. Int. 2004, 3, 102.

3. Dong, C. N.; Wang, Y.; Zhu, Y. Z. Bioorg. Med. Chem. 2009, 17, 3499.

4. Lin, Y. L.; Chang, Y. Y.; Kuo, Y. H.; Shiao, M. S. J. Nat. Prod. 2002, 65, 745.

5. Yang, H.; Cheng, J. J.; Liang, G. Chin. Pharm. Bull. 2010, 26, 1208.

6. Ai, C. B.; Li, L. N. J. Nat. Prod. 1988, 51, 145.

7. Scammells, P. J.; Baker, S. P.; Beauglehole, A. R. Bioorg. Med. Chem. 1998, 6, 1517.

8. Tsai, I. L.; Hsieh, C. F.; Duh, C. Y. Phytochem. 1998, 48, 1371.

9. Öztürk, S. E.; Akgül, Y.; Anı1, H. Bioorg. Med. Chem. 2008, 16, 4431.

10. Wang, E. C.; Wein, Y. S.; Kuo, Y. H. Tetrahedron Lett. 2006, 47, 9195.

11. Yue. D. W.; Yao, T. L.; Larock, R. C. J. Org. Chem. 2005, 70, 10292.

12. (a) Bakunov, S. A.; Bakunova, S. M.; Wenzler, T.; Barszcz, T.; Werbovetz, K. A.; Brun, 
Reto.; Tidwell, R. R. J. Med. Chem. 2008, 51, 6927. (b) Scammells, P. J.; Baker, S. P.; Beauglehole, A. R. Bioorg. Med. Chem. 1998, 6, 1517.

13. (a) Lütjens, H.; Scammells, P. J. Tetrahedron Lett. 1998, 39, 6581. (b) Cho, C. H.; Neuenswander, B.; Lushington, G. H.; Larock, R. C. J. Comb. Chem. 2008, 10, 941. (c) Bang, H. B.; Han, S. Y.; Choi, D. H.; Hwang, J. W.; Jun, J. G. ARKIVOC 2009, ii, 112. (d) Hwu, J. R.; Chuang, K. S.; Chuang, S. H.; Tsay, S. C. Org. Lett. 2005, 7, 1545.

14. (a) Zhang, G. P.; Shen, S. D.; Lei, M.; Hu, L. H. Tetrahedron 2011, 67, 5894. (b) Gan, X. W.; J, W.; Wang, W.; Hu, L. H. Org. Lett. 2009, 11, 589. (c) Cheng, Z.; Chen, A. F.; Wu, F.; Sheng, L.; Zhang, H. K.; G, M.; Li, Y. Y.; Zhang, L. N.; Hu, L. H.; Li, J. Y.; Li, J. Bioorg. Med. Chem. 2010. 18, 5915.

15. O’Malley, S. J.; Tan, K. L.; Watzke, A.; Bergman, R. G.; Ellman, J. A. J. Am. Chem. Soc. 2005, 127, 13496.

16. Pettit, G. R.; Quistorf, P. D.; Fry, J. A.; Herald, D. L.; Hamel, E.; Chapuis, J. C. J. Nat. Prod. 2009, 72, 876.

17. Markey, M. D.; Fu, Y.; Kelly, T. R. Org. Lett. 2007, 9, 3255.

18. Wang, W. L.; Chai, S. C.; Ye, Q. Z. Bioorg. Med. Chem. Lett. 2009, 19, 1080. 